\title{
Cutaneous Metastasis of Renal Cell Carcinoma
}

Received/Recebido 2021/07/13

Accepted/Aceite 2021/08/02

Published/Publicado $2021 / 09 / 30$ \section{Metástase Cutânea de Carcinoma de Células Renais}

André Cerejeira' $\odot$, Ana Rita Coelho², Miguel Costa-Silva', Filomena Azevedo' $\odot$

'Department of Dermatology and Venereology, Centro Hospitalar Universitário de São Joc̃o, Porto, Portugal

${ }^{2}$ Department of Anatomical Pathology, Centro Hospitalar Universitário de São João, Porto, Portugal

KEYWORDS - Carcinoma, Renal Cell; Skin Neoplasms/secondary.

PALAVRAS-CHAVE - Carcinoma de Células Renais; Neoplasias da Pele/secundária.

To the Editor:

We read with interest the article "Cutaneous metastasis as the presenting sign of urothelial carcinoma". ${ }^{1}$ We present a case that further illustrates the bad prognosis associated with skin metastases in patients with renal and urothelial neoplasms.

A 68-year-old woman presented to our dermatology department with a 3-month history of a rapidly enlarging, asymptomatic nodule in the occipital region. Past personal history was relevant for a clear-cell renal cell carcinoma (RCC) and left radical nephrectomy 5 years prior to presentation; the margins were then deemed clear of tumor. One month after surgery, bilateral pulmonary metastatic disease was detected through computed tomography (CT) scan and histopathologic examination. Since then, the patient had been under immunotherapy with Nivolumab, with regular follow-up and stable disease. She denied fatigue, fever, weight loss, abdominal pain, or other symptoms. Physical examination revealed an exophytic, pedunculated, firm, oval, $3 \times 2 \mathrm{~cm}$ erythematous nodule in the occipital region (Fig. 1A). No other skin lesions, lymphadenopathy, or abdominal masses were detected, and the remaining physical examination was unremarkable.

Surgical resection was performed. Histopathologic examination revealed a dermal nodular growth with a predominant solid architecture and a regular network of small, thin-walled blood vessels (Fig. 1B). It was composed of epithelioid cells with clear cytoplasm and distinct cell membranes, with inconspicuous nucleoli. PAX8 was expressed in a nuclear distribution, supporting the diagnosis of metastatic RCC (Fig. 1C). Specimen margins were free of neoplasm. A postoperative positron emission $\mathrm{CT}$ scan revealed brain nodules with metabolic activity suggestive of metastatic disease. Systemic treatment was switched to axitinib, however disease progression ensued, and the patient died six months later.

Cutaneous metastases of RCC are considered a rare phenomenon, occurring in $3 \%$ of cases of metastatic RCC. ${ }^{2}$ Single or multiple,
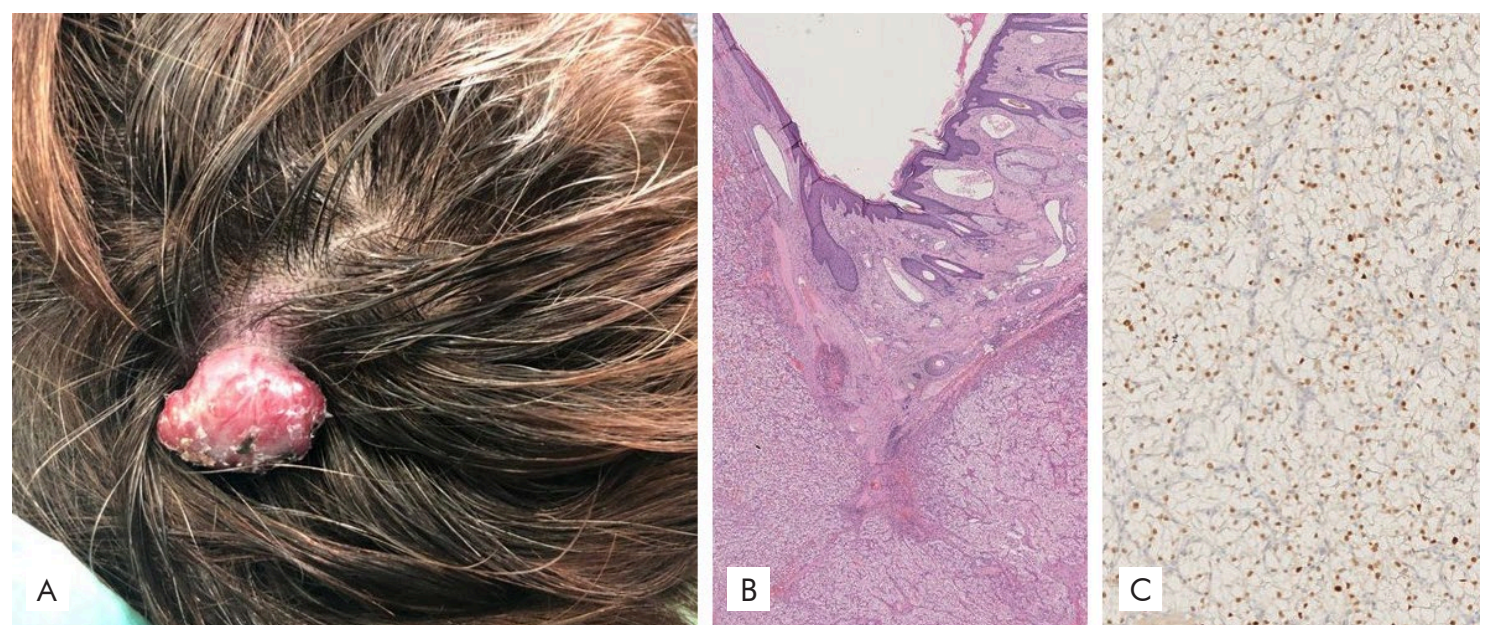

Figure 5 - (A) Exophytic, pedunculated, firm, oval, $2.5 \times 2 \mathrm{~cm}$ erythematous nodule in the occipital region. (B) Histopathologic examination revealed epithelioid cells with clear cytoplasm and irregular nuclei. (C) Immunohistochemical stain for PAX8 was positive. 
rapidly growing, asymptomatic, erythematous-violaceous nodules or tumors are typically observed. ${ }^{2}$ The most common locations are the face and the scalp. ${ }^{3}$ Arteriovenous shunts are thought to facilitate tumor dissemination to the head. ${ }^{3}$

RCC metastases on the skin can have a vascular appearance, and therefore be mistaken for a pyogenic granuloma, Kaposi sarcoma, angiosarcoma, or other vascular tumors. ${ }^{3}$ Although they are generally detected within 5 years from the primary tumor diagnosis, skin metastases occasionally develop decades later. ${ }^{4}$

The preferred approach for single, isolated skin lesions consists in surgical removal. ${ }^{5}$ However, in up to $90 \%$ of cases, concomitant visceral metastases can be found, which explains why cutaneous metastases of RCC are associated with a poor prognosis, and a tumor-specific survival of less than six months. ${ }^{6}$

RCC cutaneous metastases frequently herald the development of visceral RCC metastases, which emphasizes the role of skin examination in the follow-up of patients with this malignancy. ${ }^{3}$

Conflicts of Interest: The authors have no conflicts of interest to declare. Financing Support: This work has not received any contribution, grant or scholarship. Confidentiality of Data: The authors declare that they have followed the protocols of their work center on the publication of data from patients. Patient Consent: Consent for publication was obtained. Provenance and Peer Review: Not commissioned; externally peer reviewed.

Conflitos de Interesse: Os autores declaram a inexistência de conflitos de interesse na realização do presente trabalho. Fontes de Financiamento: Não existiram fontes externas de financiamento para a realização deste artigo. Confidencialidade dos Dados: Os autores declaram ter seguido os protocolos da sua instituição acerca da publicação dos dados de doentes. Consentimento:
Consentimento do doente para publicação obtido. Proveniência e Revisão por Pares: Não comissionado; revisão externa por pares.

\section{ORCID}

André Cerejeira: https://orcid.org/0000-0001-9416-4388

Filomena Azevedo: https://orcid.org/0000-0003-0402-6382

Corresponding Author: André Cerejeira

Address: Department of Dermatology and Venereology, Centro Hospitalar São João

Alameda Prof. Hernâni Monteiro, 4200-319 Porto, Portugal

E-mail: andrecerejeira@hotmail.com

(c) Author(s) (or their employer(s)) 2021 SPDV Journal. Re-use permitted under CC BY-NC. No commercial re-use.

(c) Autor (es) (ou seu (s) empregador (es)) 2021 Revista SPDV. Reutilização permitida de acordo com CC BY-NC. Nenhuma reutilização comercial.

\section{REFERENCES}

1. Fernandes T, Lima R, Matias A, Alves L, Souza M. Cutaneous metastasis as the presenting sign of urothelial carcinoma. Rev Soc Port Dermatol Venereol. 2020;78: 255-9. doi: 10.29021/ spdv.78.3.1203

2. Lee HJ, Lee A, Tan D, Du J, Wang Y, Tang PY, Sim AS. Cutaneous metastasis of renal cell carcinoma. Lancet Oncol. 2020;21:e292. doi: 10.1016/S1470-2045(20)30143-1.

3. Mahmoudi HR, Kamyab K, Daneshpazhooh M. Cutaneous metastasis of renal cell carcinoma: a case report. Dermatol Online J. 2012;18:12.

4. Lorenzo-Rios D, Cruzval-O'Reilly E, Rabelo-Cartagena J. Facial Cutaneous metastasis in renal cell carcinoma. Cureus. 2020;12:e12093. doi: 10.7759/cureus. 12093.

5. Ferhatoglu MF, Senol K, Filiz Al. Skin Metastasis of Renal Cell Carcinoma: A Case Report. Cureus. 2018;10:e3614. doi: 10.7759/cureus.3614.

6. Singh P, Somani K. Latent distant metastasis of renal cell carcinoma to skin: a case report Clin Case Rep. 2020;8:1138-41. doi:10.1002/ccr3.2844 